\title{
SYNTHESIS OF 4-HYDROXY-3-(1-HYDROXY-2-(SUBSTITUTEDAMINO)ETHYL)-1-PHENYL/ METHYL QUINOLIN-2(1H)-ONE AS ANTICANCER AGENTS
}

\author{
PRACHI BAJAJ, SHIVLINGRAO MAMLE DESAI*, PEARL DIGHE, SONIYA NAIK, BHEEMANAGOUDA BIRADAR
}

Department of Pharmaceutical Chemistry, P. E. S's Rajaram and Tarabai Bandekar College of Pharmacy, Farmagudi, Ponda, Goa, India. Email: smamledesai@rediffmail.com

Received: 01 April 2017, Revised and Accepted: 04 May 2017

\section{ABSTRACT}

Objective: The current work is concerned with the synthesis of a series of 4-hydroxy-3-(1-hydroxy-2-(substituted amino)ethyl)-1-phenyl/ methylquinolin-2(1H)-one[III-a(1-5)/III-b(1-5)] and evaluation of its in vitro anticancer activity.

Methods: The starting material for linomide analogs was synthesized by following literature procedures. The carbonyl group was reduced to hydroxyl group using sodium borohydride, and the methyl group was brominated using bromine in acetic acid. Further bromine was nucleophilically substituted by primary amines. All the synthesized compounds were satisfactorily characterized by infrared, nuclear magnetic resonance, and mass spectral data. The synthesized compounds were tested for in vitro anticancer activity against MDA-MB cell line using the MTT assay method.

Results: Among all the synthesized compounds, compound [III-a1; $\mathrm{R}=\mathrm{C}_{6} \mathrm{H}_{5}, \mathrm{R}_{1}=\mathrm{n}$-propylamine], [III-b1;R=CH, $\left.\mathrm{R}_{1}=\mathrm{n}-\mathrm{propylamine}\right]$, and [III$\mathrm{b} 2 ; \mathrm{R}=\mathrm{CH}_{3}, \mathrm{R}_{1}=$ methylamine] were found to be most cytotoxic with $\mathrm{IC}_{50}$ value $=25 \mu \mathrm{g}$ against the MDA-MB cell line.

Conclusion: The results of screening studies concluded that compounds with $\left(\mathrm{C}_{6} \mathrm{H}_{5}\right.$ at $\left.\mathrm{C}_{1}\right)$ and (long chain aliphatic and cyclic amines at $\left.\mathrm{C}_{3}\right)$ position of quinolin-2-one ring showed moderate activity.

Keywords: Anticancer activity, Human mammary gland, Linomide.

(C) 2017 The Authors. Published by Innovare Academic Sciences Pvt Ltd. This is an open access article under the CC BY license (http://creativecommons. org/licenses/by/4. 0/) DOI: http://dx.doi.org/10.22159/ajpcr.2017.v10i8.18836

\section{INTRODUCTION}

Cancer is characterized by uncontrolled growth of cells. It is a lifethreatening disease affecting the people of all ages and is responsible for increase in the mortality rate globally. Inspite of availability of a large number of existing anticancer drugs, the development of new chemotherapeutics have always been one of the most noteworthy challenges due to non-selectivity and emergence of resistance by cancerous cells toward existing anticancer compounds [1-3]. Linomide is a nitrogen containing pharmacophore identified as a lead molecule for anti-human immunodeficiency virus, anticancer, and anti-inflammatory agents by many researchers [4]. This leads various research workers to make an effort to synthesize linomide analogs with higher potency and fewer side effects. Quinoline and its derivatives are important in medicinal chemistry because of their wide occurrence in plants and drugs and have been reported to have wide biological activity including anticancer [5]. Linomide, an immune stimulant quinolone derivative increases natural killer cells activity and macrophage cytotoxicity. Linomide has been reported to be effective against MH-134 tumor cells and prostate cancer [6-8]. It also inhibits angiogenesis and reduces the secretion of tumor necrosis factor alpha. In the present investigation, we thought of modifying linomide structure on ring nitrogen, carbonyl group of acetyl, and replacing phenyl ring by heterocyclic ring system. Some of the compounds have shown encouraging anticancer activity against MDA-MB cell lines.

\section{METHODS}

All the chemicals used were of analytical grade obtained from Sprague-Dawley, Fine and Spectrochem. Melting points of synthesized compounds were determined by thiel's melting point apparatus and are uncorrected. Fourier Transform infrared spectra were recorded on Shimadzu IRAffinity-1 spectrophotometer using $\mathrm{KBr}$ pellets. The ${ }^{1} \mathrm{H}$ nuclear magnetic resonance $\left({ }^{1} \mathrm{H}\right.$ NMR) and ${ }^{13} \mathrm{C}$ NMR were recorded on BrukerAvance II 400 NMR spectrometer using $\mathrm{CDCl}_{3}$ or DMSO-d as solvent and tetramethylsilane as internal standard; chemical shifts are expressed as $\delta$ values (ppm). The mass spectra were recorded on Waters, Q-TOF Micromass (liquid chromatography-mass spectrometry). The starting material for the synthesis of title compounds, as shown in Scheme 1, was synthesized following literature [9]

Synthesis of ( \pm )4-hydroxy-3-(1-hydroxyethyl)-1-phenyl/methyl quinolin-2(1H)-one $\{\mathrm{I}-\mathrm{a} / \mathrm{I}-\mathrm{b}\}$

A solution of 4-hydroxy-6-methyl/phenylquinolin-2(1H)-one (0.05 M) in $10 \mathrm{ml}$ of absolute ethanol was placed in ice water bath, and then a solution of sodium borohydride $(0.01 \mathrm{M})$ in $10 \mathrm{ml}$ of cold water was added dropwise over a period of $1 \mathrm{hr}$. The mixture was then allowed to stand at room temperature for 10 minutes. $1 \mathrm{ml}$ of dilute hydrochloric acid was added to destroy any residual borohydride and then transferred to separating funnel. $20 \mathrm{ml}$ of ether was added, swirled, and the ether layer was separated, ether was removed under vaccum using rotaevoporador. The compound was dried, collected, and recystallized using benzene.

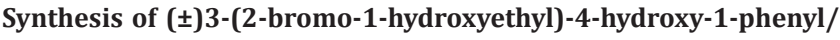
methylquinolin-2(1H)-one $\{$ II-a/II-b $\}$

A solution of I-a/I-b $(0.01 \mathrm{M})$ in acetic acid ( $8 \mathrm{ml})$ was cooled to below $20^{\circ} \mathrm{C}$ by immersion in ice bath, then bromine $(1.6 \mathrm{~g}, 0.01 \mathrm{M})$ in acetic acid ( $3 \mathrm{ml}$ ) was added dropwise with vigorous stirring over a period of $1 \mathrm{hr}$. After completion of addition of bromine, the mixture was stirred for $1 \mathrm{hr}$ at room temperature and then diluted with $2.5 \mathrm{ml}$ of water. The mixture was neutralized by the addition of $3 \mathrm{ml}$ of $40 \%$ sodium hydroxide solution. The precipitate obtained was filtered, washed with water and dried. 


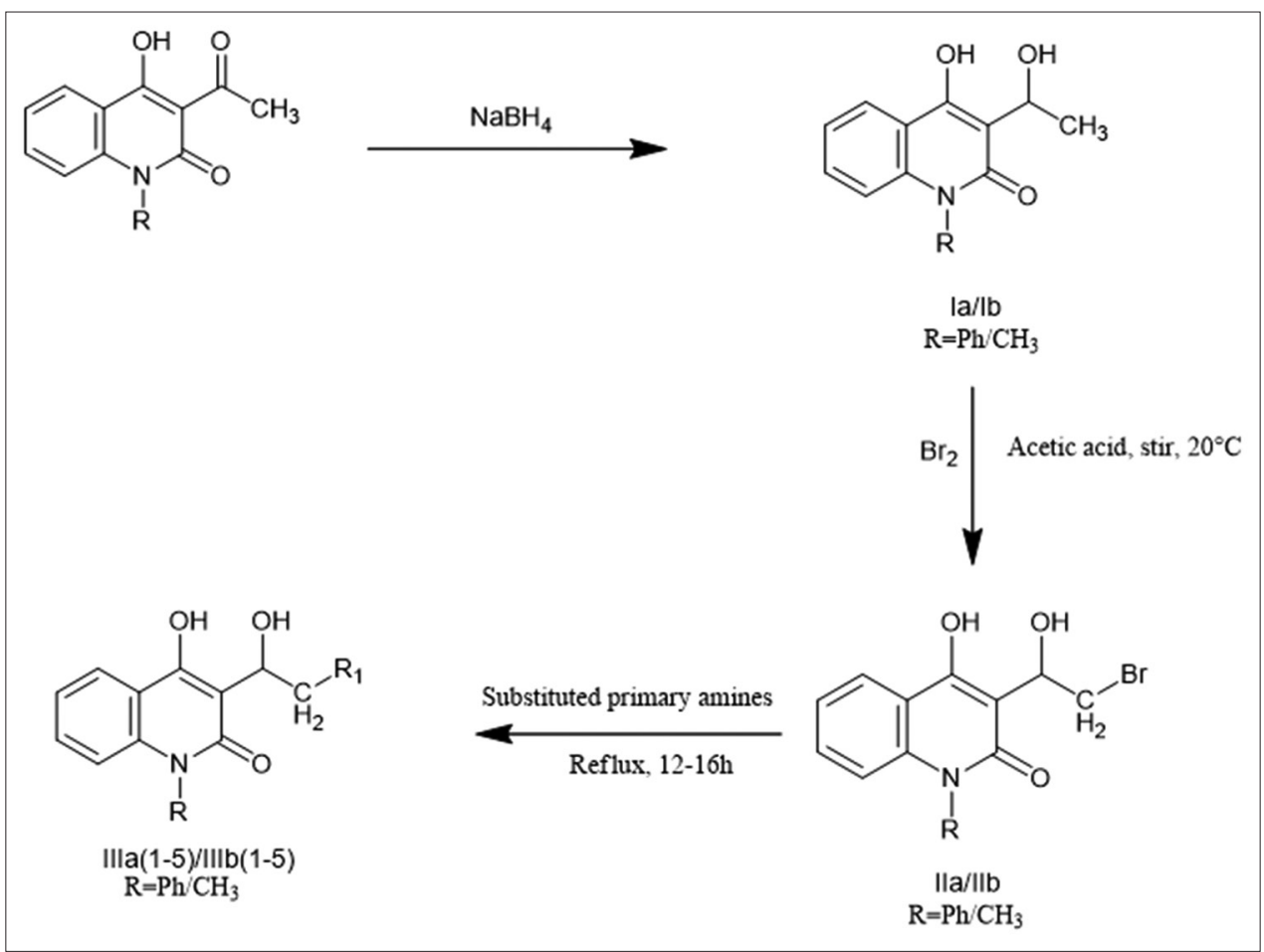

Scheme 1: Synthesis of 4-hydroxy-3-(1-hydroxy-2-(substitutedamine)ethyl)-1-phenyl/methylquinolin-2(1H)-one

Synthesis of $( \pm$ )4-hydroxy-3-(1-hydroxy-2-(substituted amino) ethyl)-1-phenyl/methyl-quinolin-2(1H)-one\{III-a(1-5)/III-b(1-5)\} A mixture of II-a/II-b $(0.05 \mathrm{M})$ and substituted primary amines $(0.05 \mathrm{M})$ in $20 \mathrm{ml}$ of absolute ethanol was heated under reflux for 12-16 hrs. After completion of the reaction, the excess solvent was distilled off under reduced pressure using rotoevaporator. The product was poured into crushed ice, filtered, washed thoroughly with water, and recrystallized using suitable solvent. The purity of all the newly synthesized compounds was ascertained by thin-layer chromatography using (n-hexane:ethyl acetate) in the ratio 7:3 as the mobile phase, silica gel $\mathrm{G}$ as stationary phase and iodine vapors as visualizing agent.

The structural data for the synthesized compounds are given in Table 1.

\section{Anticancer activity}

MTT assay method [10]

The human mammary gland (MDA-MB) cell line was obtained from the National Centre for Cell Sciences, Pune, India. The cell lines were maintained in 96 wells of microtiter plate containing minimum essential medium (MEM) media supplemented with $10 \%$ heat-inactivated fetal calf serum, containing $5 \%$ of mixture of gentamicin $(10 \mu \mathrm{g})$, penicillin

Table 1: Structural data of the newly synthesized compounds $\{$ III-a (1-5)/III-b (1-5)\}

\begin{tabular}{|c|c|c|}
\hline Compound & $\mathbf{R}$ & $\mathrm{R}_{1}$ \\
\hline $\begin{array}{l}\text { III-a1 } \\
\text { III-a2 } \\
\text { III-a3 } \\
\text { III-a4 }\end{array}$ & $\begin{array}{l}\mathrm{C}_{6} \mathrm{H}_{5} \\
\mathrm{C}_{6} \mathrm{H}_{5} \\
\mathrm{C}_{6} \mathrm{H}_{5} \\
\mathrm{C}_{6} \mathrm{H}_{5}\end{array}$ & $\begin{array}{l}\mathrm{CH}_{3}-\mathrm{CH}_{2}-\mathrm{CH}_{2}-\mathrm{NH}- \\
\mathrm{CH}_{3}-\mathrm{NH}- \\
\mathrm{CH}_{3}-\mathrm{CH}_{2}-\mathrm{NH}- \\
\triangle \mathrm{H}_{\mathrm{N}-}\end{array}$ \\
\hline $\begin{array}{l}\text { III-a5 } \\
\text { III-b1 } \\
\text { III-b2 } \\
\text { III-b3 } \\
\text { III-b4 }\end{array}$ & $\begin{array}{l}\mathrm{C}_{6} \mathrm{H}_{5} \\
\mathrm{CH}_{3} \\
\mathrm{CH}_{3} \\
\mathrm{CH}_{3} \\
\mathrm{CH}_{3}\end{array}$ & $\begin{array}{l}\mathrm{C}_{6} \mathrm{H}_{5}-\mathrm{NH}- \\
\mathrm{CH}_{3}-\mathrm{CH}_{2}-\mathrm{CH}_{2}-\mathrm{NH}- \\
\mathrm{CH}_{3}-\mathrm{NH}- \\
\mathrm{CH}_{3}-\mathrm{CH}_{2}-\mathrm{NH}- \\
\mathrm{N}_{\mathrm{H}-}-\end{array}$ \\
\hline III-b5 & $\mathrm{CH}_{3}$ & $\mathrm{C}_{6} \mathrm{H}_{5}-\mathrm{NH}-$ \\
\hline
\end{tabular}

(100 units/ml), and streptomycin $(100 \mu \mathrm{g} / \mathrm{ml})$ in presence of $5 \% \mathrm{CO}_{2}$ at $37^{\circ} \mathrm{C}$ for $48-72 \mathrm{hrs}$. The supernatant from the plate was removed, and fresh MEM solution was added and treated with different concentration of test compound appropriately diluted with dimethyl sulfoxide (DMSO). Control group contained only DMSO. After $48 \mathrm{hrs}$ of incubation at $37^{\circ} \mathrm{C}$ in a humidified atmosphere with $5 \% \mathrm{CO}_{2}$, the medium was replaced with MTT solution $(20 \mu \mathrm{l}, 5 \mathrm{mg}$ per $\mathrm{ml}$ in sterile phosphate buffered saline) for further $4 \mathrm{hrs}$ incubation. The supernatant was carefully aspirated, and the precipitated crystals of "Formazan blue" were solubilized by adding DMSO $(100 \mu \mathrm{l})$. In vitro growth inhibition effect of test compound was assessed by determination of conversion of MTT into "Formazan blue" by living cells. Optical density (OD) of the sample was measured at $492 \mathrm{~nm}$. The results represent the mean of five readings (Table 2). The percent cell lysis was calculated using the following formula:

$$
\text { Surviving cells }(\%)=\frac{\text { Mean OD of test compound }}{\text { Mean OD at control }} \times 100
$$

\section{RESULTS}

Characterization of the synthesized compounds

( \pm )4-Hydroxy-3-(1-hydroxyethyl)-1-phenylquinolin-2(1H)-one (I-a)

Yield: $70.76 \%$, m.p: $167^{\circ} \mathrm{C}$, IR $\left(\mathrm{KBr}, \mathrm{cm}^{-1}\right)$ : $3213.41(-\mathrm{OH})$; 3064.89 , 3032.10 (aromatic -C-H); 2922.16 (aliphatic-C-H str); 1646.42 (-C=O amide), ${ }^{1} \mathrm{H}$ NMR (DMSO-d ${ }_{6}, \delta$ ppm): 17.15 (s, $\left.1 \mathrm{H},-\mathrm{OH}\right) ; 8.2-6.4(\mathrm{~m}, 9 \mathrm{H}$, Ar-H); 3.93 (t, 1H, - $\mathrm{CHOH}) ; 3.36(\mathrm{~s}, 1 \mathrm{H},-\mathrm{OH}$ of $\mathrm{CHOH}) ; 2.6\left(\mathrm{~s}, 3 \mathrm{H},-\mathrm{CH}_{3}\right)$.

( \pm )4-Hydroxy-3-(1-hydroxyethyl)-1-methylquinolin-2(1H)-one $(I-b)$

Yield: 73.69\%, m.p: $70^{\circ} \mathrm{C}$, IR (KBr, cm$\left.{ }^{-1}\right)$ : 3392.79 .76 (-OH); 3099.61 (aromatic -C-H); 2976.16, 2931.80 (aliphatic -C-H str.); 1652.01 (-C=O amide), ${ }^{1} \mathrm{H}$ NMR $\left(\mathrm{CDCl}_{3}, \delta \mathrm{ppm}\right): 16.79(\mathrm{~s}, 1 \mathrm{H},-\mathrm{OH}) ; 8.1-7.0$ (m, 4H, Ar$\mathrm{H}) ; 3.75(\mathrm{t}, 1 \mathrm{H},-\mathrm{CHOH}) ; 3.72\left(\mathrm{~s}, 3 \mathrm{H},-\mathrm{N}-\mathrm{CH}_{3}\right) ; 3.5(\mathrm{~s}, 1 \mathrm{H},-\mathrm{OH}$ of $\mathrm{CHOH})$; $2.7\left(\mathrm{~s}, 3 \mathrm{H},-\mathrm{CH}_{3}\right)$. 
Table 2: In vitro anticancer activity of 4-hydroxy-3-(1-hydroxy-2-(substituedamine) ethyl)-1-phenyl/methylquinolin-2 $(1 H)$-onederivatives

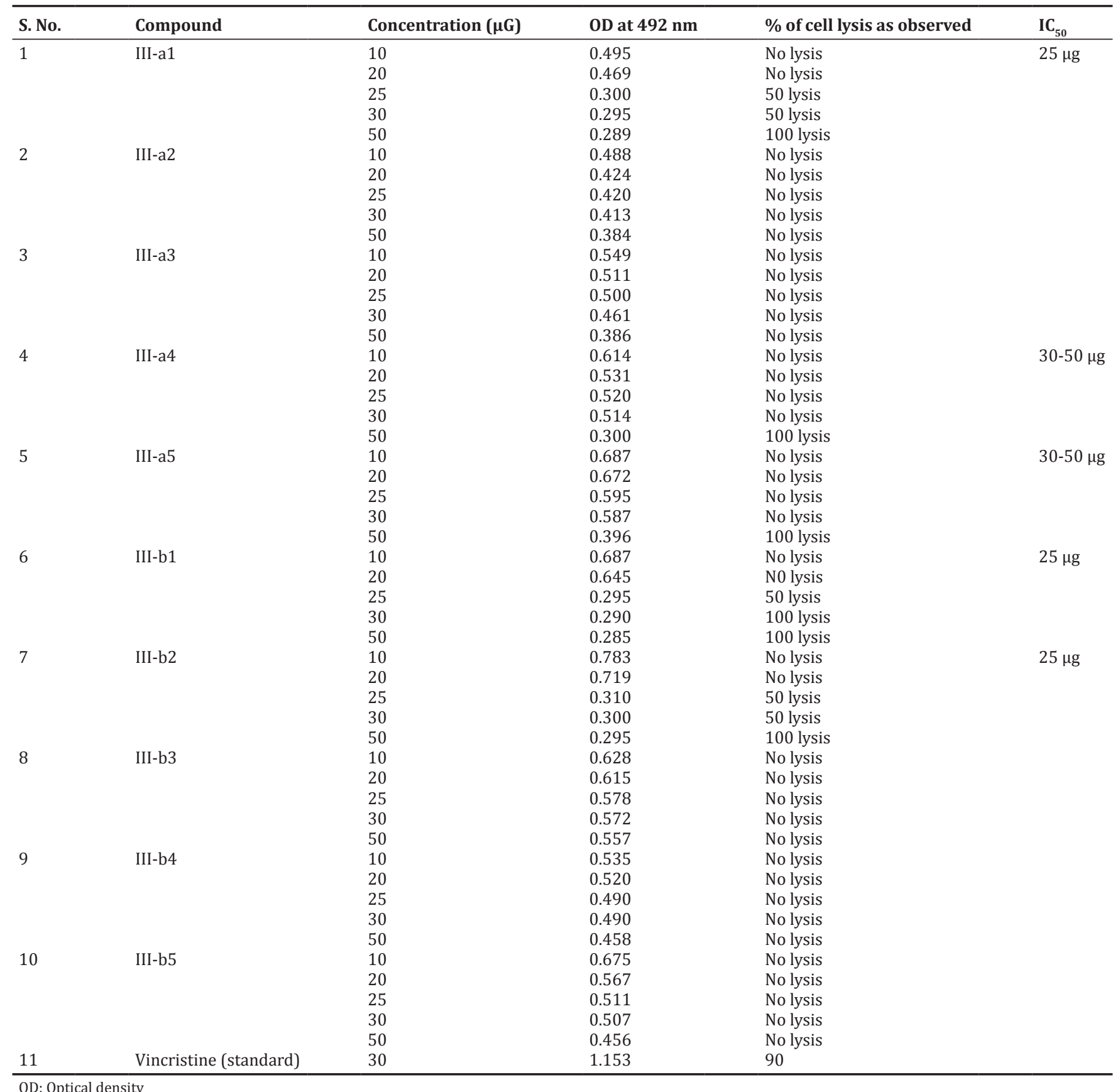

(士)3-(2-Bromo-1-hydroxyethyl)-4-hydroxy-1-phenylquinolin2(1H)-one (II-a)

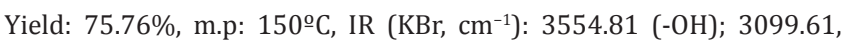
3074.53 (aromatic $\mathrm{CH}) ; 1654.92\left(-\mathrm{C}=\mathrm{O}\right.$ amide); $704.02\left(-\mathrm{CH}_{2} \mathrm{Br}\right),{ }^{1} \mathrm{H}$ NMR (DMSO- $d_{6}, \delta$ ppm): $17.15(\mathrm{~s}, 1 \mathrm{H},-\mathrm{OH}) ; 8.2-6.4(\mathrm{~m}, 9 \mathrm{H}, \mathrm{Ar}-\mathrm{H}) ; 3.93$ (t, $1 \mathrm{H},-\mathrm{CHOH}) ; 3.36(\mathrm{~s}, 1 \mathrm{H},-\mathrm{OH}$ of $\mathrm{CHOH}) ; 3.09$ (s, $2 \mathrm{H},-\mathrm{CH}_{2}$ of $\left.\mathrm{CH}_{2} \mathrm{Br}\right)$.

( \pm )3-(2-Bromo-1-hydroxyethyl)-4-hydroxy-1-methylquinolin2(1H)-one (II-b)

Yield: $79.69 \%$, m.p: $111^{\circ} \mathrm{C}$, IR (KBr, cm$\left.{ }^{-1}\right)$ : 3523 (-OH);3074.53 (aromatic -C-H); 3016.67 (aliphatic -C-H str); 1637.65 (-C=0 amide); $756.10\left(-\mathrm{CH}_{2} \mathrm{Br}\right),{ }^{1} \mathrm{H}$ NMR $\left(\mathrm{CDCl}_{3}, \delta \mathrm{ppm}\right): 16.79(\mathrm{~s}, 1 \mathrm{H},-\mathrm{OH}) ; 8.1-7.0(\mathrm{~m}$, $4 \mathrm{H}, \mathrm{Ar}-\mathrm{H}) ; 3.75(\mathrm{t}, 1 \mathrm{H},-\mathrm{CHOH}) ; 3.72\left(\mathrm{~s}, 3 \mathrm{H},-\mathrm{N}-\mathrm{CH}_{3}\right) ; 3.5(\mathrm{~s}, 1 \mathrm{H},-\mathrm{OH}$ of $\mathrm{CHOH}) ; 3.05$ (s, $2 \mathrm{H},-\mathrm{CH}_{2}$ of $\left.\mathrm{CH}_{2} \mathrm{Br}\right)$.
( \pm )4-Hydroxy-3-(1-hydroxy-2-(propylamino)ethyl)-1-phenylquinolin-2(1H)-one (III-a1)

Yield: $77.45 \%$, m.p: $140^{\circ} \mathrm{C}$, IR (KBr, cm$\left.{ }^{-1}\right): 3408.22(-\mathrm{OH}) ; 3204.89$ (-NH);3096.09,3062.96 (aromatic-C-H);2962.66, 2908.96 (aliphatic-C-H str.); 1614.42 (-C=0 amide), ${ }_{1} \mathrm{H}$ NMR $\left(\mathrm{CDCl}_{3}, \delta\right.$ ppm): 8.26 (s, $\left.1 \mathrm{H},-\mathrm{OH}\right) ; 8.1-$ 7.2 (m, 9H, Ar-H); 3.38 (s, 1H, -OH of $\mathrm{CHOH}$ ); 3.34 (t, 1H, - $\mathrm{CHOH}$ ); 2.16 (d, $\left.2 \mathrm{H},-\mathrm{CH}_{2}\right) ; 1.76(\mathrm{~s}, 1 \mathrm{H},-\mathrm{NH}) ; 1.47\left(\mathrm{t}, 2 \mathrm{H},-\mathrm{CH}_{2}\right.$ of $-\mathrm{CH}_{2} \mathrm{CH}_{2}$ ) $) ; 1.40$ (sext, $2 \mathrm{H},-\mathrm{CH}_{2}$ of $\left.\mathrm{CH}_{2} \mathrm{CH}_{3}\right) ; 0.95\left(\mathrm{t}, 3 \mathrm{H},-\mathrm{CH}_{3}\right),(\mathrm{m} / \mathrm{z})=339.11\left[\mathrm{M}^{+1}\right]$.

( \pm )4-Hydroxy-3-(1-hydroxy-2-(methylamino)ethyl)-1-phenylquinolin-2(1H)-one (III-a2)

Yield: $80.12 \%$, m.p: $133^{\circ} \mathrm{C}$, IR $\left(\mathrm{KBr}, \mathrm{cm}^{-1}\right): 3446.79(-\mathrm{OH}) ; 3202.43$ (-NH);3076.61, 3064.89 (aromatic -C-H); 2962.24 (aliphatic -C-H str.); 1631.78 (-C=0 amide), ${ }^{1} \mathrm{H}$ NMR $\left(\mathrm{CDCl}_{3}, \delta \mathrm{ppm}\right): 8.15(\mathrm{~s}, 1 \mathrm{H},-\mathrm{OH}) ; 8.1-$ 
6.5 (m, 9H, Ar-H); 4.04 (t, 1H, -CHOH); 3.25(s, 1H, -OHof CHOH); 3.22 (s, $\left.3 \mathrm{H},-\mathrm{CH}_{3}\right) ; 2.17\left(\mathrm{~d}, 2 \mathrm{H},-\mathrm{CH}_{2}\right) ; 2.05(\mathrm{~s}, 1 \mathrm{H},-\mathrm{NH})$.

( \pm )3-(2-(Cyclopropylamino)-1-hydroxyethyl)-4-hydroxy-1phenyl-quinolin-2(1H)-one (III-a4)

Yield: $72.56 \%$, m.p: $135^{\circ} \mathrm{C}$, IR $\left(\mathrm{KBr}, \mathrm{cm}^{-1}\right): 3474.81(-\mathrm{OH}) ; 3244.27$ (-NH); 3064.89, 3024.82 (aromatic -C-H); 2924.09 (aliphatic -C-H str); 1643.35 (-C=O amide), ${ }^{1} \mathrm{H}$ NMR $\left(\mathrm{CDCl}_{3}, \delta \mathrm{ppm}\right): 8.14(\mathrm{~s}, 1 \mathrm{H},-\mathrm{OH}) ; 7.9-$ 6.5 (m, 9H, Ar-H); 3.38 (t, 1H, -CHOH); 3.37 (s, 1H, -OHof $\mathrm{CHOH}$ ); 2.16 (d, $\left.2 \mathrm{H},-\mathrm{CH}_{2}\right) ; 1.8(\mathrm{~s}, 1 \mathrm{H},-\mathrm{NH}) ; 1.34$ (pent, $1 \mathrm{H},-\mathrm{CH}$ of cyclopropylamine); 1.32 (d, $4 \mathrm{H}, 2,3-\mathrm{CH}_{2}$ of cyclopropylamine).

( \pm )4-Hydroxy-3-(1-hydroxy-2-(propylamino)ethyl)-1-methylquinolin-2(1H)-one (III-b1)

Yield: $74.94 \%$, m.p: $135^{\circ} \mathrm{C}$, IR $\left(\mathrm{KBr}, \mathrm{cm}^{-1}\right): 3417.86$ (-OH); 3254.27 (-NH);3044.27 (aromatic -C-H); 2999.16, 2929.87 (aliphatic -C-H str.); $1656.16\left(-\mathrm{C}=0\right.$ amide), ${ }^{1} \mathrm{H}$ NMR $\left(\mathrm{CDCl}_{3}, \delta \mathrm{ppm}\right): 8.18(\mathrm{~s}, 1 \mathrm{H},-\mathrm{OH}) ; 8.1-7.1$ (m, 4H, Ar-H); 3.77 (t, 1H, - CHOH); $3.72\left(\mathrm{~s}, 3 \mathrm{H},-\mathrm{N}-\mathrm{CH}_{3}\right) ; 3.3$ (s, $1 \mathrm{H},-\mathrm{OH}$ of $\mathrm{CHOH}) ; 2.16\left(\mathrm{~d}, 2 \mathrm{H},-\mathrm{CH}_{2}\right) ; 1.75(\mathrm{~s}, 1 \mathrm{H},-\mathrm{NH}) ; 1.47\left(\mathrm{t}, 2 \mathrm{H},-\mathrm{CH}_{2}\right.$ of $\left.-\mathrm{CH}_{2} \mathrm{CH}_{2}-\right)$; 1.39 (sext, $2 \mathrm{H},-\mathrm{CH}_{2}$ of $\left.\mathrm{CH}_{2} \mathrm{CH}_{3}\right) ; 0.90\left(\mathrm{t}, 3 \mathrm{H},-\mathrm{CH}_{3}\right),(\mathrm{m} / \mathrm{z})=276.12\left[\mathrm{M}^{+1}\right]$.

( \pm )4-Hydroxy-3-(1-hydroxy-2-(methylamino)ethyl)-1-methylquinolin-2(1H)-one (III-b2)

Yield: $81.98 \%$, m.p: $130^{\circ} \mathrm{C}$,IR $\left(\mathrm{KBr}, \mathrm{cm}^{-1}\right): 3421.72(-\mathrm{OH}) ; 3217.27$ (-NH);3067.27 (aromatic -C-H); 2976.16, 2931.72 (aliphatic -C-H str.); $1635.64\left(-\mathrm{C}=0\right.$ amide), ${ }^{1} \mathrm{H}$ NMR $\left(\mathrm{CDCl}_{3}, \delta \mathrm{ppm}\right): 8.11(\mathrm{~s}, 1 \mathrm{H},-\mathrm{OH}) ; 7.9-6.9$ $(\mathrm{m}, 4 \mathrm{H}, \mathrm{Ar}-\mathrm{H}) ; 3.78(\mathrm{t}, 1 \mathrm{H},-\mathrm{CHOH}) ; 3.73\left(\mathrm{~s}, 3 \mathrm{H},-\mathrm{N}^{-\mathrm{CH}_{3}}\right) 3.36(\mathrm{~s}, 1 \mathrm{H},-\mathrm{OH}$ of $\mathrm{CHOH}) ; 3.33\left(\mathrm{~s}, 3 \mathrm{H},-\mathrm{CH}_{3}\right) ; 2.17\left(\mathrm{~d}, 2 \mathrm{H},-\mathrm{CH}_{2}\right) ; 2.03(\mathrm{~s}, 1 \mathrm{H},-\mathrm{NH})$

\section{DISCUSSION}

As mentioned in the scheme, we have synthesized two series of quinolin-2-one derivatives which include $(\mathbf{\pm}) 4$-hydroxy-3-(1-hydroxy2-(substituted amino)ethyl)-1-phenyl-quinolin-2(1H)-one (III-a series) and( \pm )4-hydroxy-3-(1-hydroxy-2-(substituted amino)ethyl)-1methyl-quinolin-2(1H)-one (III-b series). The acetyl group compound Ia $\backslash$ Ib was reduced by $\mathrm{NaBH}_{4}$ to the corresponding chiral alcohol and halogenation with bromine in acetic acid gave $\beta$-haloalcohol. In the final step, halogen was substituted by primary amine nucleophiles. MTT assay is a colorimetric assay that measures the reduction of yellow 3-(4,5-dimethythiazol-2-yl)-2,5-diphenyl tetrazolium bromide (MTT) by mitochondrial succinate dehydrogenase. Since the reduction of MTT can only occur in metabolically active cells the level of activity is a measure of the viability of the cells.

\section{CONCLUSION}

A series of ( \pm )4-hydroxy-3-(1-hydroxy-2-(substituted amino)ethyl)-1phenyl/methylquinolin-2(1H)-one derivatives were synthesized and evaluated for their anticancer activity by MTT assay method. From the obtained result, it was concluded that, among all, compound (III-a1), (III-b1), and (III-b2) were found to be most potent with IC $_{50}$ value $=25 \mu \mathrm{g}$ whereas compound (III-a4) and (III- a5) showed moderate activity with $\mathrm{IC}_{50}$ value $=30-50 \mu \mathrm{g}$ and were therefore found to be active against the in vitro anticancer activity. The results of screening studies suggested that compounds with $\mathrm{C}_{6} \mathrm{H}_{5}$ at $\mathrm{C}_{1}$ and long chain aliphatic and cyclic amines at $\mathrm{C}_{3}$ position of quinolin-2-one ring showed moderate activity.

Thus, research work was undertaken for substitution at $3^{\text {rd }}$ position of quinolin-2-one ring. The encouraging results shown may lead to the development of novel anticancer drugs, if explored further.

\section{ACKNOWLEDGMENT}

The authors are thankful to Director NMR and MASS Center, Panjab University Chandigarh, India, for providing necessary spectra and analysis.

\section{REFERENCES}

1. Ramanivas T, Sushma B, Nayak VL, Chandra Shekar K, Srivastava AK. Design, synthesis and biological evaluations of chirally pure 1,2,3,4-tertrahydroisoquinoline analogs as anti-cancer agents. Eur J Med Chem 2015;92:608-18.

2. Gottesman MM. Mechanisms of cancer drug resistance. Annu Rev Med 2002;53:615-27

3. de Martel C, Ferlay J, Franceschi S, Vignat J, Bray F, Forman D, et al. Global burden of cancers attributable to infections in 2008: A review and synthetic analysis. Lancet Oncol 2012;13(6):607-15.

4. Sravanthi TV, Rani S, Manju S. Synthesis and biological evaluation of 2-(2'/3'/4'/6'-substitutedphenyl)-1H-indoles. Int J Pharm Pharm Sci 2015;7(11):268-73.

5. Ahmed SM, Mohamed E, Sanaa ME. 2,4-cycloaddition reactions: Preparation and cytotoxicity of novel quinoline and pyrrolo-[3,4-f]quinoline derivatives. Int J Pharm Pharm Sci 2015;7(12):64-8.

6. Abbas P, Alizera F, Mehdi H, Saeed R. In-vitro cytotoxicity and phototoxicity of N-piperzinyl quinolone derivatives with a 2-thienyl group. Toxicol In Vitro 2007;21:1031.

7. Chen YL, Chung $\mathrm{CH}$, Chen IL, Chen PH, Jeng HY. Synthesis and cytotoxic activity evaluation of indolo-, pyrrolo-, and benzofuroquinolin-2(1H)-ones and 6-anilinoindoloquinoline derivatives. Bioorg Med Chem 2002;10(8):2705-12.

8. George CP, Elizabeth MJ. Cancer Immunotherapy. $2^{\text {nd }}$ ed. San Diego, CA: Academic Press; 2012.

9. Anisha R, Shivalingrao M, Soniya N, Prassad T. Synthesis of 4-methoxy1-phenyl/methyl-3-[5-(phenyl/substitutedphenyl)-,5-dihydro-( $1 H)$ one derivatives as a antibacterial agents. Indian J Heterocyclic Chem 2015;25:173.

10. Mosmann T. Rapid colorimetric assay for cellular growth and survival: Application to proliferation and cytotoxicity assays. J Immunol Methods 1983;65(1-2):55-63. 